\title{
Sinonasal Inverted Papilloma
}

\author{
Thapa N. , Pradhan B. \\ Rhinology and Allergy unit, Ganesh Man Singh Academy of ENT-Head and Neck Studies, IOM, Maharajgunj, Kathmandu, \\ Nepal
}

Correspondence to: Dr. Narmaya Thapa, Rhinology \& Allergy unit, Ganesh Man Singh Academy of ENT-Head and Neck Studies, Maharajgunj, Kathmandu, Nepal

Phone Number : 977-9851056589

Email : Narmayat@gmail.com

\begin{abstract}
Introduction: Sinonasal inverted papilloma is a rare tumour comprising about $0.5-4 \%$ of total nose and paranasal sinus tumours. Though various factors have been implicated its exact cause is unknown. This longitudinal, prospective study was carried out to find out demographical profile, association of this tumour with smoking, occupation, variation with ethnic races and outcome of surgery.

Methods: This study was carried out in the department of ENT-HNS, Tribhuvan University Teaching Hospital, Maharajgunj, Kathmandu from April, 2005 to March, 2011.

Result: Out of 34 patients, there were 25 male and 9 female with ratio of 2.78:1. Age of the patients ranged from 14-76 years with median age of 51.5 \pm 2.74 SE years. Disease was more common in 4 th to 7 th decade. It was common in farmers (20). Eighteen patients were smoker and 16 nonsmoker. The disease was more common in mongoloids than in Indo-aryans. Out of 16 patients having stage III disease, 9 were smoker and 7 nonsmoker. Eighteen patients underwent endoscopic medial maxillectomy and 15 patients underwent medial maxillectomy via lateral rhinotomy approach. One patient who had bilateral disease underwent medial maxillectomy via lateral rhinotomy on the left side and endoscopically on the right side. There was recurrence of tumour in 2 patients who underwent surgery via lateral rhinotomy approach whereas in 1 patient who underwent surgery endoscopically.
\end{abstract}

Conclusion: This study showed that sinonasal inverted papilloma was common in mongoloids than in Indo-aryans and farmers but no association with smoking. Endoscopic medial maxillectomy has less reccurence of tumour in comparison to lateral rhinotomy approach.

Key words: endoscopic medial maxillectomy, lateral rhinotomy, occupation, race, recurrence, smoking, sinonasal inverted papilloma.

\section{Introduction}

Sinonasal inverted papilloma is a rare tumour . It is also known by various names as Schneiderian papilloma, epithelial papilloma, Ringertz's tumour, transitional cell papilloma, villiform cancer, Ewing's papilloma etc. ${ }^{1}$. It was first described by Ward in 1854 and Billroth in $1855 .^{2}$ Its typical histological description was given by Ringertz in $1938 .{ }^{3}$ It comprises about $0.5-4 \%$ of total nose and paranasal sinus tumours. ${ }^{1}$ It is a benign tumour but has a high propensity of recurrence and association with synchronous and metachronous malignancies. ${ }^{4}$ It occurs more commonly in male than in females with ratio of $3: 1$ and most patients are usually diagnosed in the 5 th to 7 th decades with average age of 53 years though it has been reported in children, adolescents and elderly also with age ranging from 3-89 years. ${ }^{1,5}$

Various aetiological factors have been implicated such as viral infection, allergy, smoking, occupation etc. but exact 
aetiology is still unknown. ${ }^{4}$

We carried out this longitudinal, prospective study to find out demographical profile, association of this tumour with smoking, occupation, variation with ethnic races and outcome of surgery.

\section{Methods}

This study was carried out in the department of ENT-HNS, Tribhuvan University Teaching Hospital, Maharajgunj, Kathmandu, Nepal from April, 2005 to March, 2011. All the patients were discussed in Rhinology and Allergy special clinic with CECT Scan and punch biopsy (HPE) report. Those patients whose HPE report came out to be inverted papilloma were randomly subjected for medial maxillectomy either via lateral rhinotomy or endoscopic approach. After admission detailed history taking and examination was carried out. Patients' demograpgic profile, clinical features, CTScan, peroperative findings and postoperative HPE report were noted in a specially prepared form. Writen consent was taken. Patients were followed up postoperatively.

Preoperative CTScan findings were classified according to Krouse. ${ }^{6}$

\section{Inclusion Criteria}

1. Patient who underwent primary surgery for inverted papilloma

\section{Exclusion Criteria}

1. Patient who lost follow up

2. Patient whose postoperative histopathological report came out to be other than inverted papilloma.

Chi-squire test and Fisher's exact test was applied to analise the data and the result was analised using SPSS 16. P value equal to or less than 0.05 was considered statistically significant.

\section{Results}

During above mentioned period total 35 patients underwent medial maxillectomy for sinonasal inverted papilloma. One patient lost follow up, therefore, only 34 patients were included in the study. Age of the patients ranged from 1476 years with median age of $51.5 \pm 2.74$ SE years. Disease was more common in 4 th to 7 th decade
Table 1: Distribution of age of the patients

$\begin{array}{ll}\text { Age group(years) } & \text { No. of patients } \\ <20 & 2 \\ 21-30 & 0 \\ 31-40 & 7 \\ 41-50 & 7 \\ 51-60 & 6 \\ 61-70 & 8 \\ >70 & 4\end{array}$

Male female ratio was 2.66:1

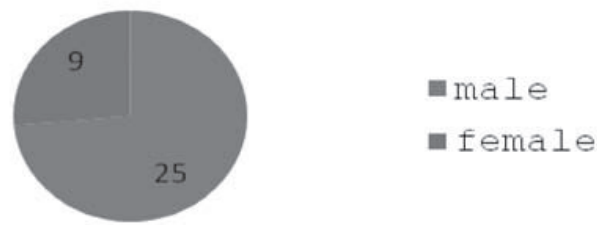

Fig.1: Distribution of gender

Disease was almost equal in number on either side whereas in 1 patient it was bilateral.

Table 2: Laterality of tumour

$\begin{array}{ll}\text { Side } & \text { No. of patients } \\ \text { Right } & 16 \\ \text { Left } & 17 \\ \text { Bilateral } & 1\end{array}$

It was common in farmers (20)

Table 3: Occupation

Occupation

No. of patients

$\begin{array}{ll}\text { Farmer } & 20 \\ \text { Service } & 4 \\ \text { House wife } & 4 \\ \text { Student } & 2 \\ \text { Painter } & 1 \\ \text { Roda factory worker } & 1 \\ \text { Journalist } & 1 \\ \text { Carpenter } & 1\end{array}$

Eighteen patients were smoker whereas 16 were nonsmoker (Fig.2). The disease was more common in mongoloids (21) 
than in Indo-aryans (13) .

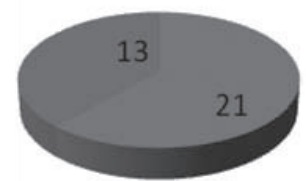

Mongoloid

- Caucasian

Fig. 2: Distribution of tumour according to race

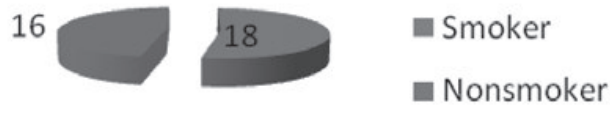

Fig. 3: Association of tumour with smoking

Out of 34 patients, 16 patients had stage III disease, of these, 9 were smokers and 7 were nonsmoker.

Table 4: Symptoms

$\begin{array}{ll}\text { Symptoms } & \text { No. of patients } \\ \text { Nasal obstruction } & 34 \\ \text { Blood mixed nasal discharge } & 12 \\ \text { Loss of smell } & 12 \\ \text { Nasal mass } & 8 \\ \text { Change in voice } & 7 \\ \text { Sneezing } & 2 \\ \text { Frequent clearing of throat } & 2 \\ \text { Watering of eye } & 2 \\ \text { Headache } & 1\end{array}$

Unilateral nasal obstruction was the predominant symptom (34) followed by blood mixed nasal discharge and decreased smell present in 12 and 11 patients respectively.

Table 5: Association of staging of tumour with smoking

\begin{tabular}{llllll} 
smoking & \multicolumn{5}{c}{ stage } \\
& I & II & III & IV & Total \\
smoker & 2 & 6 & 9 & 1 & 18 \\
nonsmoker & 1 & 7 & 7 & 1 & 16 \\
Total & 3 & 13 & 16 & 2 & 34
\end{tabular}

Chi-square test: $\mathrm{p}$ value 0.544 (statistically not significant)
Four patients had undergone intranasal polyp avulsion (INPA) and 4 patients had functional endoscopic sinus surgery (FESS) before. In 21 patients there was pale polypoidal mass along with fleshy mass and purely fleshy mass was found only in 13 patients.

Table 6: Peroperative findings

$\begin{array}{ll}\text { Findings } & \text { No. of patients } \\ \text { Pale polypoidal mass with } & 21 \\ \text { fleshy mass } & \\ \text { Purely fleshy mass } & 13\end{array}$

Eighteen patients underwent endoscopic medial maxillectomy and 15 patients underwent medial maxillectomy via lateral rhinotomy approach. One patient who had bilateral disease underwent medial maxillectomy via lateral rhinotomy on the left side and endoscopically on the right side. There was recurrence of tumour in 2 patients who underwent surgery via lateral rhinotomy approach whereas in 1 patient who underwent surgery endoscopically.

Table 7: Approaches of surgery

\begin{tabular}{lll} 
Approach & No. of patients & recurrence \\
\hline Endoscopic & 18 & 15 \\
Lateral rhinotomy & 1 & 1 \\
Combined & 2 & 0 \\
(Left lateral rhinotomy+Right endoscopic) &
\end{tabular}

Fisher's exact test: $p$ value 0.01464 ( statistically significant)

In all the patients postoperative HPE report came out to be inverted papilloma. Follow up period ranged from 6 months to 6 years.

\section{Discussion}

As mentioned earlier sinonasal inverted papilloma is a rare tumour. We encountered 35 patients in 6 years but 1 patient lost follow up. Tumour was common in 4 th to 7 th decades and common in male which is consistent with other studies et al.4 Smokers and nonsmokers were nearly equal in number. In order to compare this finding we could not find similar studies done before anywhere. Disease was more common in farmers, the reason behind this may be main occupation of Nepalese being farming and they are more prone to be exposed to various chemicals (fertilizers). Similarly the disease was found more common in mongoloids. This 
finding is more or less consistent with previous study done in eastern part of Nepal.7 Polypoidal mass along with fleshy mass was seen in many patients. This may indicate that sinonasal inverted papilloma may be associated with nasal polyp and deep biopsy is necessary otherwise HPE report may mislead the diagnosis and treatment. 8 The tumour is usually unilateral but bilateral involvement has also been reported by Yiotaki 9 We had 1 patient having bilateral disease. Recurrence was more in cases of medial maxillectomy via lateral rhinotomy approach. Many other studies have shown similar result.10-19

The limitation of this study is that it was done only in one center with small number of patients and there may be selection bias for approaches of surgery.

\section{Conclusion}

This study showed that sinonasal inverted papilloma was common in mongoloids than in Indo-aryans and farmers but there was no association with smoking. Endoscopic medial maxillectomy has less reccurence of tumour in comparison to lateral rhinotomy approach. Further study will be carried out with larger number of patients to validate these results.

\section{References}

1. Bielamowicz S, Calcaterrra TC, Watson D. Inverting papilloma of the head and neck: the UCLA update.Otolaryngol Head Neck Surg. 1993;109: 71-6.

2. Kramer R, Som ML. True papilloma of the nasal cavity. Arch Otolaryngol. 1935;22-43.

3. Ringertz N. Pathology of malignant tumors arising in the nasal and paranasal cavities and maxilla. Acta Otolaryngol (Stockh).1938;27(Suppl):31-42.

4. Sauter A, Matharu R, Horman K, et al. Current advances in the basic research and clinical management of Sinonasal inverted papilloma (review). Oncol Rep 2007;17: 495-504.

5. Roland DE. Inverted papilloma of the nose and paranasal sinuses in childhood and adolescence. The Laryngoscope 2009; 95 (1): $17-23$.

6. Krouse JH. Development of a staging system for inverted papilloma. Laryngoscope. 2000;110: 965968.

7. Bhandary S, Singh RK, Shrestha S, Sinha AK, Badhu BP, Karki P. Sinonasal inverted papilloma in eastern part of Nepal. Kathmandu University Medical Journal. 2006; 4(16):431-435.
8. Phillips PP, Gustafson RO, Facer GW. The clinical behavior of inverting papilloma of the nose and paranasal sinuses: report of 112 cases and review of the literature. Laryngoscope 1990;100:463-69.

9. Yiotakis J, Hantzakos A, Kandiloros D, Ferekidis E. A rare location of bilateral inverted papilloma of the nose and paranasal sinuses. Rhinology. 2002 Dec; 40 (4):220-2.

10. Pasquini E, Sciarretta V, Farneti G, et al. Inverted papilloma: report of 89 cases. Am J Otolaryngol 2004; 25:178-85.

11. Busquets JM, Hwang PH. Endoscopic resection of sinonasal inverted papilloma: a metaanalysis. Otolaryngol Head Neck Surg 2006;134:476-82.

12. Tomenzoli D, Castelnuovo P, Pagella F, et al: Different endoscopic surgical strategies in the management of inverted papilloma of the sinonasal tract: experience with 47 patients. Laryngoscope 2004; 114: 193-200.

13. Kaza S, Casiano RR. Endoscopic resection of inverted papilloma: University of Miami experience. Am J Rhinol 2000;17: 185-190.

14. Kraft M, Kaufmann T, Holzmann D. Long-term results of endonasal sinus surgery in sinonasal papillomas Laryngoscope 2003; 113: 1541-1547.

15. Lawson W, Ho BT, Shaari CM and Biller HF. Inverted papilloma: a report of 112 cases. Laryngoscope. 1995; 105: 228-288.

16. Minovi A, Kollert M, Draf W, Bockmuhl U. Endonasal micro-endoscopic resection of sinonasal inverted papilloma. Laryngorhinootologie. 2006;85:421-425.

17. Iqbal SM, Khan IA, Khan IZ, Malik S. Inverted papillomas of the nose and sinuses: clinical presentation, surgical treatment and outcome. Journal of Surgery Pakistan (International) 2008; 13(2): 8587.

18. Sharma V, Koirala K. lateral rhinotomy vs midfacial degloving for T3 inverted papilloma of nose and paranasal sinus. Nepal Med coll J. 2009; 11(2) : 115117.

19. Wolfe SG, Schlosser RJ, Bolger WE, Lanza DC, Kennedy DW. Endoscopic and endoscope-assisted resections of inverted sinonasal papillomas. Otolaryngol Head Neck Surg. 2004 Sep;131(3):174-9. 